\title{
A monoclonal ELISA for bovine viral diarrhoea pestivirus antigen detection in persistently infected cattle
}

B. Mignon, J. Dubuisson, E. Baranowski, I. Koromyslov*, E. Ernst, D. Boulanger, S. Waxweiler and P.P. Pastoret Department of Virology-Immunology, Faculty of Veterinary Medicine, Institut de Chimie, Sart Tilman-Liège, Belgium

(Accepted 8 July 1991)

\section{Summary}

Detection of cattle persistently infected with bovine viral diarrhoea virus (BVDV) is crucial to controlling mucosal disease. A sandwich enzyme-linked immunosorbent assay (ELISA) using monoclonal antibodies raised against the 48-kDa glycoprotein and the 120/80-kDa protein was developed for detecting antigens in leucocytes of 3 persistently BVDV-infected calves. The test is simple, sensitive and rapid. Moreover the same ELISA was able to recognise Belgian field isolates of BVDV. These results show that the test can be applied in the field.

ELISA; Bovine viral diarrhoea virus; Monoclonal antibody

\section{Introduction}

Bovine viral diarrhoea virus (BVDV) is a major pathogen of cattle (Pastoret et al., 1986) causing bovine viral diarrhoea and mucosal disease. Antigenically, BVDV is closely related to the border disease virus (BDV) of sheep and to hog cholera virus (HCV) (Edwards et al., 1988). All three viruses belong to the

\footnotetext{
*Present address: All-Union Institute of Experimental Veterinary Medicine, (VIEV) Kuzminki 109472, Moscow, U.S.S.R.

Correspondence to: B. Mignon, Dept. of Virology-Immunology, Faculty of Veterinary Medicine ULg., Institut de Chimie (B6) - local R80, B-4000 Sart Tilman-Liège, Belgium.
} 
genus Pestivirus within the Togaviridae family (Westaway et al., 1985). However, recent data on their genomic organisation and expression strategy suggest that the pestiviruses should be classified as a genus within the Flaviviridae family (Renard et al., 1985; Collett et al., 1988).

Two biotypes (cytopathic and non-cytopathic) are detectable in vitro. A distinguishing feature of the cytopathic biotype is the cleavage of a $120-\mathrm{kDa}$ non-structural protein resulting in an $80-\mathrm{kDa}$ polypeptide (Donis and Dubovi, 1987; Pocock et al., 1987). BVDV infection can lead to a pleomorphic pathology, of which persistent infections are a key phenomenon. Only persistently viraemic animals can subsequently develop mucosal disease. Furthermore, such animals constantly excrete large amounts of virus which maintain infections within herds. The economic losses due to BVDV infection, especially persistent infection, have prompted new control strategies (Pastoret et al., 1989). Although the percentage of persistent excretors of the virus is usually less than 1\% (Meyling, 1984), it can be much higher in some herds (Roeder and Drew, 1984). Given the central role of the persistent excretor in the epidemiology of BVDV infection, detection of such animals is crucial to controlling the disease.

Methods of detecting BVDV are time-consuming, expensive and lack sensitivity, because it is necessary to amplify the virus and detect it indirectly, i.e. by immunofluorescence (Waxweiler et al., 1989). Recently, an ELISA has been developed for detecting sheep persistently infected with BVD (Fenton et al., 1990). For capture, this test uses a monoclonal antibody (mAb) directed against the $120-\mathrm{kDa}$ protein, and to reveal the antigen, a polyvalent antiserum raised against this protein. We here describe a new ELISA for rapid detection of BVDV antigen in leucocytes of persistently BVDV-infected cattle.

Following the suggestion that specific mAbs can be used as diagnostic tools (Cay et al., 1989), combinations of mAbs raised against the $120 / 80-\mathrm{kDa}$ nonstructural protein and against the $48-\mathrm{kDa}$ glycoprotein are used both for capture and for demonstrating the presence of the antigen.

\section{Materials and Methods}

Viruses and cells

The non-cytopathic New York (NY) BVDV strain, cloned three times, was used throughout this study. Madin Darby bovine kidney cells (MDBK), grown in minimum essential medium (MEM) containing $5 \%$ of calf serum, were used for viral propagation. Twenty-eight non-cytopathic Belgian field isolates of BVDV were also used in this work. For titration, virus multiplication was revealed by indirect immunofluorescence (IIF). Viral titres were recorded in TCID $_{50}$. 
Animals

Three persistently BVDV-infected calves (87, 88 and 89) obtained by experimental inoculation (Mignon et al., 1990) were used as antigen sources. One uninfected calf (991) was used as a control.

\section{Monoclonal antibodies}

Production of hybridomas and characterization of mAbs have been described previously (Boulanger et al., 1991). The eighteen mAbs (Table 1) used in ELISAs were purified on protein A-Sepharose CL-4B (Pharmacia) by the procedure of Ey et al. (1978) as modified by Seppälä et al. (1981). Purified mAbs were biotinylated (Biotin H-1759, Sigma) according to Goding (1980). The activity of purified mAbs was estimated by an indirect immunofluorescence assay, using MDBK cells infected with the NY strain (Mignon et al., 1990).

\section{TABLE 1}

Properties of mAbs used in ELISAs

\begin{tabular}{|c|c|}
\hline Antibody ${ }^{a}$ & Relative affinity ${ }^{c}$ \\
\hline \multicolumn{2}{|c|}{ - specific for the $48-\mathrm{kDa}$ glycoprotein ${ }^{\mathrm{b}}$} \\
\hline 1 & low \\
\hline 2 & low \\
\hline 3 & low \\
\hline 4 & low \\
\hline 5 & low \\
\hline 6 & high \\
\hline 7 & low \\
\hline 8 & high \\
\hline 11 & high \\
\hline 12 & low \\
\hline 13 & low \\
\hline 14 & low \\
\hline 15 & high \\
\hline \multicolumn{2}{|c|}{ - specific for the $120 / 80-k$ Da protein ${ }^{b}$} \\
\hline 21 & low \\
\hline 22 & high \\
\hline 23 & high \\
\hline 24 & high \\
\hline 25 & high \\
\hline
\end{tabular}

${ }^{a}$ All mAbs were from the $\operatorname{IgG}_{1}$ isotype (Boulanger et al., 1991).

'Determined by radioimmunoprecipitation (Boulanger et al., 1991).

'Determined by an indirect ELISA. The relative affinities were classified as low $\left(A_{414}<0.2\right.$ for anti48-kDa mAbs and $A_{414}<0.1$ for anti-120/80-kDa mAbs) and high $\left(A_{414}>0.4\right.$ for anti-48-kDa $\mathrm{mAbs}$ and $A_{414}>0.2$ for anti-120/80-kDa mAbs). 
The relative affinities of $\mathrm{mAbs}$ raised against either the $48-\mathrm{kDa}$ glycoprotein or the $120 / 80-\mathrm{kDa}$ protein were determined by titration in an indirect ELISA. Parallel experiments using a single antigen preparation were conducted at the same time for all mAbs targeting the same protein. BVDV was partially purified according to a modification of the method described by Wensvoort et al. (1986). Briefly, two-day NY-infected monolayers were frozen and thawed twice and centrifuged $(100000 \times g$ for $4 \mathrm{~h})$ through a cushion of $25 \%$ sucrose in phosphate-buffered saline (PBS: $3 \mathrm{mM} \mathrm{KCl}, 1.5 \mathrm{mM} \mathrm{KH}{ }_{2} \mathrm{PO}_{4}, 0.14 \mathrm{M}$ $\mathrm{NaCl}, 6.5 \mathrm{mM} \mathrm{Na} \mathrm{HPO}_{4} 2 \mathrm{H}_{2} \mathrm{O}, \mathrm{pH}$ 7.4). Pellets were resuspended in a small volume of $\mathrm{PBS}$, sonicated for $30 \mathrm{~s}$ and stored at $-80^{\circ} \mathrm{C}$ until used. The same procedure was applicd to non-infected control monolaycrs. ELISA plates (Nunc) were coated overnight at $4^{\circ} \mathrm{C}$ with an appropriate dilution of the antigen or control in $0.035 \mathrm{M}$ carbonate buffer ( $\mathrm{pH}$ 9.6). Plates were blocked with $0.4 \%$ skimmed milk (Gloria) in PBS-ELISA (PBS - $0.02 \%$ Tween 80 ) for $1 \mathrm{~h}$ at $37^{\circ} \mathrm{C}$. Serial three-fold dilutions of purified mAbs were then incubated for $1 \mathrm{~h}$ at $37^{\circ} \mathrm{C}$. Peroxidase-labelled anti-mouse rabbit IgGs (Dakopatts) diluted $1 / 500$ were added, and kept for $1 \mathrm{~h}$ at $37^{\circ} \mathrm{C}$. Substrate (ABTS, Boehringer-Mannheim) was then incubated for $4 \mathrm{~h}$ at room temperature and the colour development was measured with a Titertek multiscan, using a 414nm filter. Wash steps were performed by rinsing the plates 5 times with PBSELISA. Antibody and conjugate dilutions were made in $0.2 \%$ skimmed milk in PBS-ELISA. Throughout the procedure, 100- $\mu$ l reagent volumes were used, except for the blocking step ( $200 \mu \mathrm{l}$ per well). For each dilution of one $\mathrm{mAb}$, the absorbance value was calculated from the mean of three measurements made with antigen and control. The relative affinities of $\mathrm{mAbs}$ were estimated using the absorbance value of the ELISA at the plateau level as described by Frankel and Gerhard (1979) and Underwood (1988).

\section{Competitive binding assays}

$m A b s$ having a high relative affinity and raised against the same protein were used in reciprocal competitive direct ELISAs for antigenic mapping.

For anti-48-kDa mAbs, tests were performed on NY-infected cells (MOI $=$ $0.66 \mathrm{PFU} /$ cell) grown for two days in 96-well plates and fixed for $45 \mathrm{~min}$ at $-20^{\circ} \mathrm{C}$ in acetone/distilled water $(95: 5, \mathrm{v} / \mathrm{v})$. For anti-120/80-kDa mAbs, antigen was prepared as above. After the blocking step, appropriate dilutions of the competing purified $\mathrm{mAb}$ were incubated for $1 \mathrm{~h}$ at $37^{\circ} \mathrm{C}$. Plates treated with anti-120/80-kDa mAbs were washed with PBS-ELISA before adding the biotinylated $\mathrm{mAb}$. This washing step was omitted when using anti-48-kDa mAbs. The biotinylated $\mathrm{mAb}$ was used at a predetermined optimal concentration and incubated for $1 \mathrm{~h}$ at $37^{\circ} \mathrm{C}$. This was followed by incubation with 1000-fold diluted biotinylated streptavidin-horseradish peroxidase (Amersham) and ABTS substrate. 
The percentage of competition was calculated as described by KimuraKuroda and Yasui (1983), using the formula $(100(A-n)) /(A-B)$, where $A$ is the absorbance in the absence of competitive antibody, $B$ the absorbance in the presence of homologous antibody and $n$ the absorbance in the presence of competitor.

\section{Sandwich ELISA}

The capture-purified $\mathrm{mAb}(500 \mathrm{ng}$ per well diluted in carbonate buffer) was coated on ELISA plates for one night at $4^{\circ} \mathrm{C}$. Plates were washed 5 times, between each of the subsequent steps, with PBS-ELISA. This buffer was also used to dilute all subsequent reagents except the substrate. Antigen or control was incubated for $1 \mathrm{~h}$ at $37^{\circ} \mathrm{C}$. Then, the biotinylated purified $\mathrm{mAb}$ was added and incubated for $1 \mathrm{~h}$ at $37^{\circ} \mathrm{C}$ before further incubation for $1 \mathrm{~h}$ at $37^{\circ} \mathrm{C}$ with biotinylated streptavidin-horseradish peroxidase (dilution 1/1000; Amersham). Addition of ABTS substrate and colour development were performed as described above. Throughout the procedure, $100 \mu$ l reagent volumes were used. Antigen in this test was supplied as a viral suspension. The BVDV strains used were the NY strain $\left(6.3 \cdot 10^{6} \mathrm{TCID}_{50}\right.$ per $\left.\mathrm{ml}\right)$ and 26 other field isolates. Three concentrations (1, 0.1 and $0.01 \mathrm{ng}$ per well) of biotinylated mAb were used. Three preparations of antigen were compared: BVDV antigen obtained from culture supernatant, BVDV antigen from frozen and thawed inoculated monolayers, and BVDV antigen obtained after lysis of infected cells with a non-ionic detergent. In the latter case, infected cells were incubated with lysis buffer $\left(0.15 \mathrm{M} \mathrm{NaCl}, 1 \% \mathrm{NP} 40,0.05 \mathrm{M}\right.$ Tris-HCl, 0.1 mM PMSF, $1 \% \mathrm{NaN}_{3}$, $\mathrm{pH}$ 7.4) for $30 \mathrm{~min}$ at room temperature and centrifuged for $15 \mathrm{~min}$ at $10000 \times$ $g$. The supernatant was used as antigen. We then applied Student's $t$-test for pairing series based on the comparison, to zero, of the mean of the absorbance differences for all dilutions of 2 antigen preparations.

\section{Detection of persistently BVDV-infected calves}

The sandwich ELISA was used to detect antigen in the blood of persistently BVDV-infected calves. Preparation of antigen was performed according to Fenton et al. (1990). Briefly, 30-ml heparinised blood samples were collected from calves $87,88,89$ and 991 . They were centrifuged for $30 \mathrm{~min}$ at $1000 \times g$ to obtain white blood cells which were then washed with PBS. Red cells were lysed with ammonium chloride $\left(0.144 \mathrm{M} \mathrm{NH}_{4} \mathrm{Cl}, 17 \mathrm{mM}\right.$ Tris- $\left.\mathrm{HCl}, \mathrm{pH} 7.2\right)$. Two washes yielded the final leucocyte pellet. Cells were counted and viral titres were estimated in order to determine the detection threshold (in TCID S0 $_{\text {) }}$ of the sandwich ELISA in infected animals. The pellet was treated with NP40 and used as antigen. Student's $t$-test, based on the comparison of two means (in the case of small samples), was applied to compare absorbance values obtained in viraemic animals with those of the control calf. 


\section{Results}

Competitive binding assays

mAbs exhibiting high relative affinities were used in reciprocal competitive binding assays. Among the anti-120/80-kDa mAbs, those chosen were 22, 23, 24 and 25 (see relative affinities in Fig. 1, Table 1). Competition percentages are shown in Table 2. Reciprocal and symmetrical reactions between mAbs 23 and 24 suggest that these mAbs recognise identical, overlapping or adjacent epitopes. When used as a competitor, mAb 25 showed total competition with $\mathrm{mAbs} 23$ and 24 . The competition was only partial, however, when $\mathrm{mAb} 25$ was used as detecting $\mathrm{mAb}$. This suggests that the epitope identified by $\mathrm{mAb} 25$

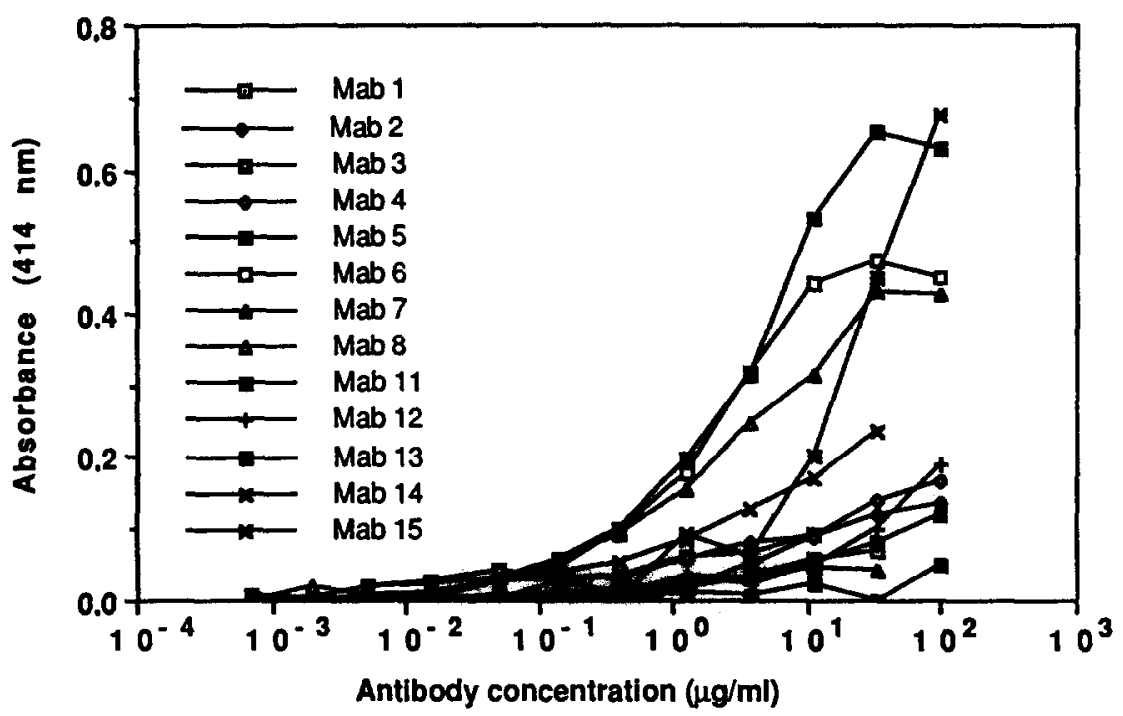

Fig. 1. Relative affinities of mAbs raised against the 120/80-kDa protein measured by indirect ELISA.

\section{TABLE 2}

Determination of the reciprocal competition between mAbs raised against $120 / 80-\mathrm{kDa}$ protein as measured by direct ELISA

\begin{tabular}{lcrrr}
\hline Unlabelled mAb & \multicolumn{2}{l}{ Labelled mAb } & 24 & 25 \\
\cline { 2 - 5 } & 22 & 23 & 22 & 49 \\
\hline 22 & $100^{\mathrm{a}}$ & 9 & 100 & 73 \\
23 & 45 & 100 & 100 & 67 \\
24 & 28 & 101 & 98 & 100 \\
25 & 106 & 99 & 9 \\
\hline
\end{tabular}

${ }^{\text {a }}$ Percentage of competition $>75 \%$ : total competition; $25 \%<$ percentage of competition $<75 \%$ : partial competition; percentage of competition $<25 \%$ : absence of competition. 
TABLE 3

Determination of the reciprocal competition between mAbs raised against 48-kDa glycoprotein as measured by direct ELISA

\begin{tabular}{llrr}
\hline Unlabelled mAb & \multicolumn{2}{l}{ Labelled mAb } & \multicolumn{1}{l}{11} \\
\cline { 2 - 4 } & 6 & 8 & 69 \\
\hline 6 & $100^{\mathrm{a}}$ & 86 & 86 \\
8 & 86 & 100 & 100 \\
11 & 89 & 109 & 4 \\
15 & 14 & 5 & $5 \%$ \\
\hline
\end{tabular}

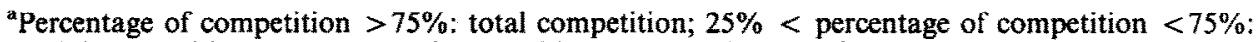
partial competition; percentage of competition $<25 \%$ : absence of competition.

could be adjacent to those identified by mAbs 23 and 24 . Likewise, the competition between mAbs 22 and 25 was reciprocal but non-symmetrical, suggesting that the corresponding epitopes could be adjacent. No competition was observed between mAbs 23 or 24 and mAb 22 .

The anti-48-kDa mAbs used in the competitive binding assays were mAbs 6 , 8,11 and 15 (see relative affinities in Table 1). Competition percentages are given in Table 3 . Reciprocal and symmetrical competition between mAbs 6,8 and 11 suggests that the epitopes identified by these mAbs are identical, overlapping or adjacent. None of these mAbs compete with $\mathrm{mAb} 15$, suggesting that the latter's target belongs to another antigenic domain.

\section{Sandwich ELISA}

In sandwich ELISAs, the BVDV antigen was detected by five anti-120/80$\mathrm{kDa} m A$ bairs $(22-23,22-24,24-25,25-23,25-24)$ (Fig. 2). Among the anti-48-

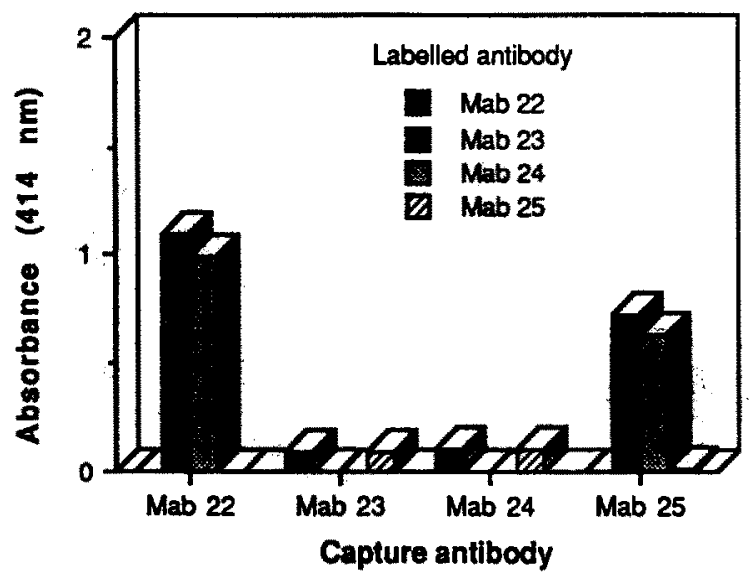

Fig. 2. Determination of the sensitivity of the sandwich ELISA for pairs of $m A$ bs exhibiting a high relative affinity and raised against the $120 / 80-\mathrm{kDa}$ protein. Labelled $\mathrm{mAbs}$ were used at the concentration of $0.1 \mu \mathrm{g}$ per ml. 


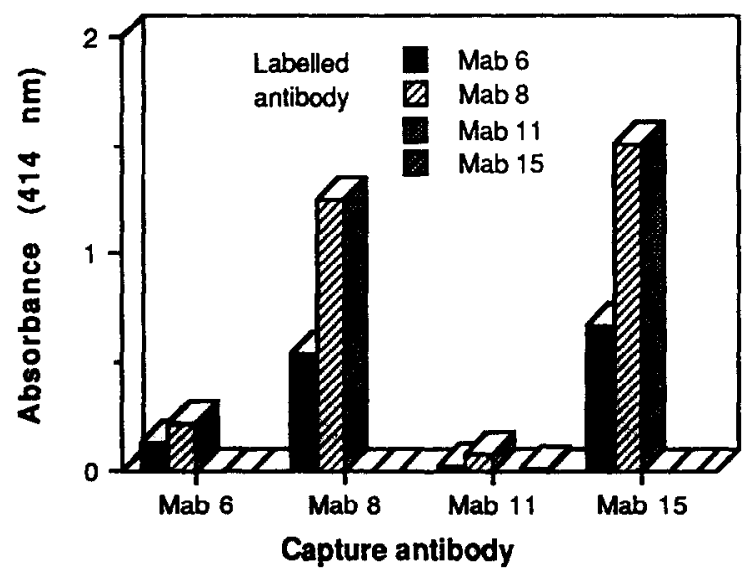

Fig. 3. Determination of the sensitivity of the sandwich ELISA for pairs of mAbs exhibiting a high relative affinity and raised against the $48-\mathrm{kDa}$ glycoprotein. Labelled $\mathrm{mAbs}$ were used at a concentration of $0.1 \mu \mathrm{g}$ per ml.

kDa mAb pairs, only six $(6-6,6-8,8-8,8-6,15-6,15-8)$ yielded positive results, the most sensitive pair being 15-8 (Fig. 3).

The sensitivity was higher when the antigen was prepared from NP40-treated infected cells rather than frozen and thawed cells $(t=2.653, P<0.025$ for the

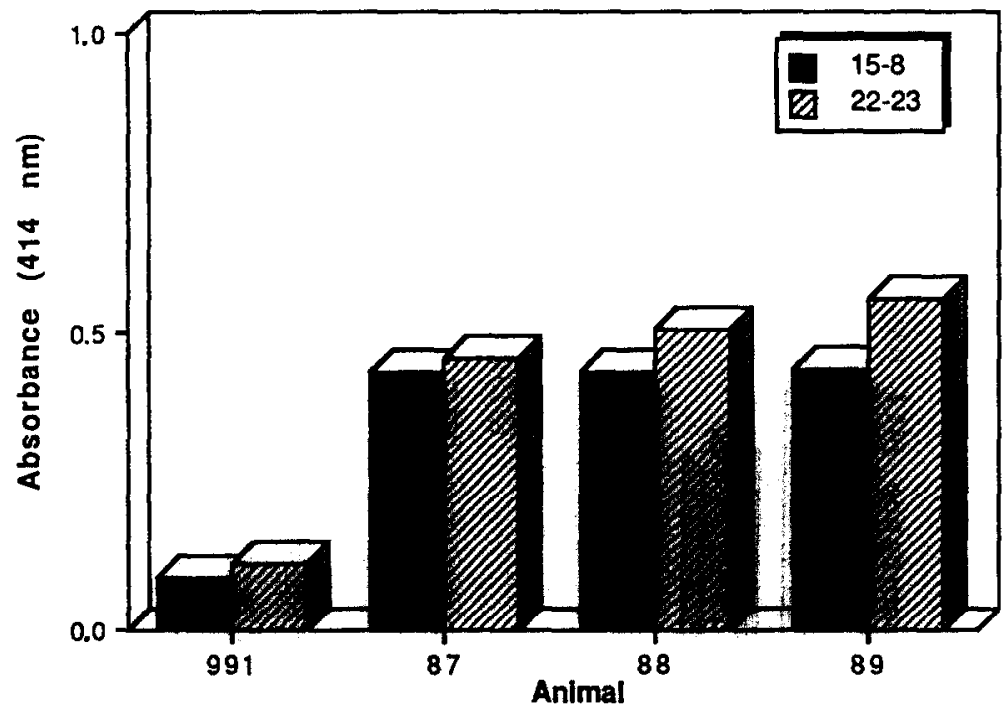

Fig. 4. Detection by sandwich ELISA of BVDV antigens (48-kDa glycoprotein and 120/80-kDa protein) in NP40-treated buffy coat obtained from three persistently BVDV-infected calves (87, 88 and 89$)$. Capture antibody was used at a concentration of $500 \mathrm{ng}$ per well. The amount of antigen per well was that extracted from $1.5 \mathrm{ml}$ of blood sample before treatment. The concentrations of detecting antibody were 100 and 25 ng per well for mAbs 23 and 8, respectively. 
pair 22-23; $t=3.65, P<0.005$ for the pair 15-8). The sandwich ELISA did not detect viral antigen from culture supernatant $\left(9 \cdot 10^{5} \mathrm{TCID}_{50}\right.$ per $\left.\mathrm{ml}\right)$ indicating that antigen must be obtained from infected cells.

The respective detection threshold for pairs $15-8$ and $22-23$ in these assays were $1.95 \cdot 10^{2}$ and $7.81 \cdot 10^{2}$ TCID $_{50}$.

All $28 \mathrm{BVDV}$ field isolates were detected by each combination of $\mathrm{mAbs}$ tested (data not shown).

Detection of persistently BVDV-infected calves

Two pairs of mAbs, 22-23 (anti-120/80-kDa) and 15-8 (anti-48-kDa), were used in the sandwich ELISA. This test detected viral antigen in three persistently BVDV-infected calves as shown by the absorbance values obtained: in each case, the difference with respect to the control value is significant ( $t$ varying from 8 to $99 ; P<0.0125$ ) (Fig. 4). Under these conditions, the detection threshold of the test was less than 1000 TCID $_{50}$.

\section{Discussion}

We have developed a monoclonal sandwich ELISA for detecting viral antigens in the leucocytes of persistently BVDV-infected animals.

Our aim is to detect as many infected animals as possible, so our assay must target proteins whose sequence is conserved among the various BVDV strains. Such is indeed the case: the $120 / 80-\mathrm{kDa}$ protein is almost $100 \%$ homologous in the two non-cytopathic BVDV strains NADL and Osloss, and the 48-kDa glycoprotein is quite conserved among BVDV strains (Collett et al., 1988). It therefore comes as no surprise that all the mAbs used in this work recognise most of the BVDV reference strains (Boulanger et al., 1991) and the 28 field strains tested.

The reason for determining the relative affinities of the mAbs is double: firstly, the quantity of mAb used in the sandwich ELISA can be reduced by discarding mAbs whose relative affinity is too low; secondly, should the epitope of the tested strain be slightly modified, a high-affinity mAb should still conserve enough binding energy, despite some loss, to recognise the epitope (Underwood, 1988). This is less likely if the relative affinity is already low.

All pairs of mAbs having a high relative affinity for the same protein were tested in sandwich ELISAs. The capture antibody concentration, $500 \mathrm{ng}$ per well, can be reduced (data not shown) and must be optimized in the future. The adsorption step was carried out for one night at $4^{\circ} \mathrm{C}$, but can be shortened to 2 $h$ if performed at $37^{\circ} \mathrm{C}$ (data not shown). In this way, the whole test can be completed within one day.

Among pairs of mAbs raised against the $120 / 80-\mathrm{kDa}$ protein, pairs $23-24$ and 24-23 failed to detect any BVDV antigen. This is in keeping with competitive binding assays: mAbs 23 and 24 recognise overlapping or closely 
adjacent epitopes. Pairs 22-23 and 22-24 were the most sensitive, probably because there is a considerable distance between the epitope identified by $\mathrm{mAb}$ 22 and those identified by mAbs 23 and 24 .

Among combinations of $\mathrm{mAbs}$ raised against the 48-kDa glycoprotein, pairs 15-6 and 15-8 exhibited high sensitivity; here again, a long distance between corresponding epitopes is a likely explanation. Combinations 6-6, 6-8, 8-6 all identified the BVDV antigen. The use of a viral suspension as a source of antigen may be the reason: a BVDV particle presents the $48-\mathrm{kDa}$ glycoprotein in multiple copies on its envelope, thus allowing binding of capture and detecting antibodies raised against identical or adjacent epitopes. Moreover, assembly of the 48-kDa protein into oligomers, as observed for alphaviruses (Harrison, 1986) may provide a more plausible explanation.

The sandwich ELISA was sensitive enough to detect viraemia in three persistently infected calves. Fenton et al. (1990) recently described a sandwich ELISA for detecting another pestivirus. In their assay, only the capture antibody was a mAb, one raised against the 120/80-kDa protein. In our study, the detecting antibody is also a mAb. It can thus be produced indefinitely with constant quality. Furthermore, we have increased the assay's reactivity spectrum by targeting two different proteins and using several combinations of mAbs to detect each one. Such an approach will be necessary in the field in order to avoid false negatives. The 28 field isolates were recognised by eight pairs of mAbs, suggesting that the ELISA is more sensitive than the IIF test, in which some of these mAbs failed to recognise several strains (Boulanger et al., 1991).

This is the first report of a sandwich ELISA using several combinations of $m A b s$ raised against two different proteins for the detection of BVDV antigen in persistently infected animals. The test is simple, sensitive and rapid. First results show that it can be applied in the field but further evaluation is required.

\section{Acknowledgements}

We would like to thank M. Loncar and L. Karelle-Bui-Thi for excellent technical assistance and L. Kasprzak for typing the manuscript. This work was supported by grants from the Institut pour l'encouragement de la Recherche Scientifique dans l'Industrie et l'Agriculture (IRSIA) and Rhône-Mérieux Company. J. Dubuisson is a Senior Research Assistant of the Fonds National Belge de la Recherche Scientifique (FNRS).

\section{References}

Boulanger, D., Waxweiler, S., Karelle, L., Loncar, M., Mignon, B., Dubuisson, J., Thiry, E. and Pastoret, P.P. (1991) Characterization of monoclonal antibodies to bovine viral diarrhoea virus: evidence of a neutralizing activity against $\mathrm{gp} 48$ in the presence of goat anti-mouse immunoglobulin serum. J. Gen. Virol. 72, 1195-1198. 
Cay, B., Chappuis, G., Coulibaly, C., Dinter, Z., Edwards, S., Greiser-Wilke, I., Gunn, M., Have, P., Hess, G., Juntti, N., Liess, B., Mateo, A., McHugh, P., Moennig, V., Nettleton, P. and Wensvoort, G. (1989) Comparative analysis of monoclonal antibodies against pestiviruses: report of an International Workshop. Vet. Microbiol. 20, 123-129.

Collett, M.S., Larson, R., Gold, C., Strick, D., Anderson, D.K. and Purchio, A.F. (1988) Molecular cloning and nucleotide sequence of the pestivirus bovine diarrhoea virus. Virology 165, 191-199.

Donis, R.O. and Dubovi, E.J. (1987) Differences in virus-induced polypeptides in cells infected by cytopathic and non-cytopathic biotypes of bovine virus diarrhoea-mucosal disease virus. Virology $158,168-173$.

Edwards, S., Sands, J.J. and Harkness, J.W. (1988) The application of monoclonal antibody panels to characterize pestivirus isolates from ruminants in Great Britain. Arch. Virol. 102, 197-206.

Ey, P.L., Prowse, S.J. and Jenkin, C.R. (1978) Isolation of pure $\operatorname{IgG}_{1}, \operatorname{IgG}_{2 a}$ and $\operatorname{IgG}_{2 b}$ immunoglobulins from mouse serum using protein-A Sepharose. Immunochemistry 15, 429-436.

Fenton, A., Entrican, G., Herring, J.A. and Nettleton, P.F. (1990) An ELISA for detecting pestivirus antigen in the blood of sheep persistently infected with border disease virus. J. Virol. Methods 27, 253-260.

Frankel, M. and Gerhard, W. (1979) The rapid determination of binding constants for antiviral antibodies by a radioimmunoassay. An analysis of the interaction between hybridoma proteins and influenza virus. Mol. Immunol. 16, 101-106.

Goding, J.W. (1980) Antibody production by hybridomas. J. Immunol. Methods 39, 285-308.

Harrison, S.C. (1986) In: S. Schlessinger and M. Schlessinger (Eds), The Togaviridae and Flaviviridae. Plenum Publishing, New York, pp. 21-34.

Kimura-Kuroda, J. and Yasui, K. (1983) Topographical analysis of antigenic determinants on envelope glycoprotein V3 (E) of Japanese encephalitis virus, using monoclonal antibodies. J. Virol. 45, 124-132.

Meyling, A. (1984) Detection of the BVD virus in viraemic cattle by an indirect immunoperoxydase technique. In: M.S. McNulty and J.B. McFerran (Eds), Recent Advances in Virus Diagnosis. Martinus Nijhoff, Boston, pp. 37-46.

Mignon, B., Schwers, A., Waxweiler, S., Boulanger, D., Dubuisson, J., Brownlie, J. and Pastoret, P.P. (1990) Etude de la stabilité antigénique d'une souche non cytopathogène du virus BVD chez des animaux infectés expérimentalement de manière persistante. Ann. Méd. Vét. 134, 325-329.

Pastoret, P.P., Thiry, E., Schwers, A. and Dubuisson, J. (1986) Epidémiologie et physiopathologie de l'infection par le virus BVD. Congress, Société française de buiatrie, 6-7/11/1986, Paris. In: Pestiviroses des ovins et des bovins: nouvelles connaissances, utilisation comme stratégie de contrôle, pp. 87-104.

Pastorel, P.P., Detal, G., Dive, M., Waxweiler, S., Thiry, E., Wellemans, G., Marcourt, J., Magonet, P. and Dernelle, E. (1989) Mesures à prendre au centre de sélection bovine de Ciney en vue de répondre aux nouvelles normes sanitaires imposées par la Commission des Communautés européennes. Ann. Méd. Vét. 133, 247-256.

Pocock, D.H., Howard, C.J., Clarke, M.C. and Brownlie, J. (1987) Variation in the intracellular polypeptide profiles from different isolates of bovine virus diarrhoea virus. Arch. Virol. 94, 4353.

Renard, A., Guiot, C., Schmetz, D., Dagenais, L., Pastoret, P.P., Dina, D. and Martial, J. (1985) Molecular cloning of bovine viral diarthea virus sequences. DNA 4, 429-438.

Roeder, P.L. and Drew, T.W. (1984) Mucosal disease of cattle: a late sequel to fetal infection. Vet. Rec. 114, 309-313.

Seppälä, I., Sarvas, H., Peterfy, F. and Makela, O. (1981) The four subclasses of IgG can be isolated from mouse serum by using protein-A Sepharose. Scand. J. Immunol. 14, 335-349.

Underwood, A. (1988) Measurement of the affinity of antiviral antibodies. Adv. Virus Res. 34, 283309.

Waxweiler, S., Karelle-Bui Thi, L., Sneyers, M., Lambert, A.F., Delchambre, M., Dubuisson, J., Thiry, E., Antoine, H., Dive, M., Detal, G. and Pastoret, P.P. (1989) Circulation de souches noncytopathogènes du virus BVD-MD dans des lots de taurillons. Ann. Méd. Vét. 133, 681 -690. 
Wensvoort, G., Terpstra, C., Boonstra, J., Bloemraad, M. and Van Zaane, D. (1986) Production of monoclonal antibodies against swine fever virus and their use in laboratory diagnosis. Vet. Microbiol. 12, 101-108.

Westaway, E.G., Brinton, M.A., Gaidamovitch, S.Ya., Horzinek, M.C., Igaraski, A., Kaarainen, L., Lvov, D.K., Porterfield, J.S., Russel, P.K. and Trent, D.W. (1985) Togaviridae. Intervirology $24,125-139$. 